\section{Safety of monitoring antiretroviral therapy response in HIV-1 infection using CD4+ T cell count at long-term intervals}

\author{
Segurança do monitoramento da resposta à \\ terapia antirretroviral em pacientes com infecção \\ pelo HIV-1 através da contagem de linfócitos \\ T CD4+ a intervalos mais longos
}
Seguridad en la monitorización de la respuesta a la terapia antirretroviral ante el VIH-1, usando el recuento celular CD4+ T en intervalos a largo plazo

Ingridt Hildegard Vogler 1 Daniela Frizon Alfieri 1

Heloisa Damazio Bruna Gianjacomo 2 Elaine Regina Delicato de Almeida 2 Edna Maria Vissoci Reiche 1

\begin{abstract}
The latest Brazilian guideline recommended the reduction of routine CD4+ $T$ cell counts for the monitoring of patients with human immunodeficiency virus type $1(H I V-1)$ under combination antiretroviral therapy (cART). The aim of this study was to evaluate the safety of monitoring response to cART in HIV-1 infection using routine viral load at shorter intervals and CD4+T cell count at longer intervals. CD4+T cell counts and HIV-1 viral load were evaluated in 1,906 HIV-1-infected patients under cART during a three-year follow-up. Patients were stratified as sustained, non-sustained and non-responders. The proportion of patients who showed a CD $4+T>350 \mathrm{cells} / \mu \mathrm{L}$ at study entry among those with sustained, non-sustained and non-responders to cART and who remained with values above this threshold during follow-up was $94.1 \%, 81.8 \%$ and $71.9 \%$, respectively. HIV-1-infected patients who are sustained virologic responders and have initial CD $4+T$ cell counts $>350$ cells/ $\mu L$ showed a higher chance of maintaining the counts of these cells above this threshold during follow-up than those presenting CD $4+T \leq 350$ cells $/ \mu L$ $(O R=39.9 ; 95 \% C I: 26.5-60.2 ; p<0.001)$. This study showed that HIV1-infected patients who had sustained virologic response and initial CD4+T $>350$ cells/ $\mu L$ were more likely to maintain CD4+ T cell counts above this threshold during the next three-year follow-up. This result underscores that the evaluation of $C D 4+T$ cell counts in longer intervals does not impair the safety of monitoring $c A R T$ response when routine viral load assessment is performed in HIV-1-infected patients with sustained virologic response.
\end{abstract}

CD4 Lymphocyte Count; HIV-1; Highly ActiveAntiretroviral Therapy;

Viral Load

\author{
Correspondence \\ E. M. V. Reiche \\ Departamento de Patologia, Análises Clínicas e Toxicológicas, \\ Centro de Ciências da Saúde, Universidade Estadual de \\ Londrina. \\ Av. Robert Koch 60, Londrina, PR 86038-440, Brasil. \\ reiche@sercomtel.com.br \\ 1 Centro de Ciências da Saúde, Universidade Estadual de \\ Londrina, Londrina, Brasil. \\ 2 Hospital Universitário Universidade Estadual de Londrina, \\ Londrina, Brasil.
}




\section{Introduction}

Laboratory monitoring of patients infected with human immunodeficiency virus type 1 (HIV-1) includes CD4+ T lymphocyte counts and HIV-1 viral load (VL) quantification. CD4+ T cell is a laboratory biomarker to assess the degree of impairment of the immune system and has been used for stratifying individuals who are candidates to start combined antiretroviral therapy (cART) and for monitoring patients over time. This biomarker has been used to indicate immunization or prophylaxis for opportunistic infections, as well as to evaluate the recovery of immune response after an adequate cART 1. RNA HIV-1 VL quantification is important to the early detection of virologic failure, which is characterized by two sequentially detectable results in the course of cART 2.

Since 2006, the Brazilian clinical protocol for HIV-1 infection management recommended testing both CD4+ T cell and HIV-1 VL every 3-4 months 3 . In 2013, an update in this guideline recommended the evaluation of HIV-1 VL every 6 months 2 . In 2015, this same guideline was revised, establishing that patients under cART that are asymptomatic, with undetectable VL and CD $4+\mathrm{T}$ cell $>350$ cells $/ \mu \mathrm{L}$ in two consecutive determinations at an interval longer than six months, have no recommendations for CD4+ T cell medical request as it brings no benefit to clinical monitoring, as well as unnecessary costs 4 . At laboratory practice, we observed a certain resistance from clinicians and patients in accepting this recommendation.

In an attempt to contribute to this question, we considered performing a longitudinal study more relevant, encompassing a considerable number of individuals carefully followed from cART onset to evaluate the safety of monitoring cART response in HIV-1 infection using routine VL at short-term intervals and $\mathrm{CD} 4+\mathrm{T}$ cell count at long-term intervals.

\section{Subjects and methods}

A longitudinal follow-up study was performed with outpatient HIV-1-infected individuals with medical request for CD4+ T cell and HIV-1 VL who attended at the University Hospital of Londrina, Paraná State, Brazil, from 2012 to 2015. Data were obtained in convenience of time and place by consulting the Control System for Laboratory Tests (SISCEL), an on-line application developed by the Brazilian Ministry of Health for management of both CD4+ T cell and HIV-1 VL. This study was conducted in accordance with the Declaration of Helsinki and was approved by the local Ethics Research Committee (CAAE 44127215.0.0000.5231). Considering that this study was based on a database query, an informed consent was not obtained from the patients; however, to guarantee confidentiality, we consecutively identified the patient records/data by number prior to analysis.

All 1,906 patients included were aged $\geq 15$ years old, under cART, and performing routine laboratory attendance with at least one annual examination of CD4+ T cell and HIV-1 VL from 2012 to 2015. CD4+ T cell were evaluated using flow cytometry (BD FACS Calibur; Biociences BD, San Jose, USA) and expressed as cells/ $\mu$ L. RNA HIV-1 VL were quantified using branched-DNA (bDNA) with lower detection limit of 50 copies/mL (bDNA, Versant HIV-1 RNA 3.0 Assay; Siemens Healthcare, Malvern, USA), or quantitative polymerase chain reaction (qPCR) with lower detection limit of 40 copies/mL (Abbott Real Time HIV-1; Abbott Molecular Inc., Des Plaines, USA), according to the available reagent sets provided by the Brazilian Public Network, and both results were expressed as copies $/ \mathrm{mL}$ and $\log _{10}$ copies $/ \mathrm{mL}$. CD $4+\mathrm{T}$ cell count and HIV-1 VL were evaluated at baseline and throughout a three-year follow-up. For the purposes of this study, CD4+ T cell $>350$ cells $/ \mu \mathrm{L}$, and HIV-1 VL $<50$ copies $/ \mathrm{mL}\left(<1.70 \log _{10}\right.$ copies $\left./ \mathrm{mL}\right)$ were considered as complete immunologic and virologic responses to cART, respectively 5 .

Patients were stratified into three groups based on their virologic response status: sustained responders (undetectable HIV-1 VL during follow-up), non-sustained responders (baseline undetectable HIV-1 VL, but detectable in the follow-up), and non-responders (baseline detectable HIV-1 VL that remained detectable during the follow-up). 


\section{Statistical analysis}

Data were analyzed using the IBM SPSS program version 20 (https://www.ibm.com/). We calculated the median and interquartile range (IQR) of $25 \%$ and $75 \%$ of continuous variables, and comparison between groups was conducted using the Kruskal-Wallis test. Demographic characteristics were categorized and described as absolute number (n) and relative frequency (\%), and analyzed using chisquare test $\left(\chi^{2}\right)$. Logistic multinomial regression analysis was performed using variables with initial $\mathrm{p}<0.25$. Cochran-Mantel-Haenszel test was performed to compare independent groups of virologic response across the initial CD4+ $\mathrm{T}$ cell count with the immunologic outcome. The level of significance for the tests was set at 0.05 .

\section{Results}

\section{Demographic and laboratorial characteristics of subjects}

The 1,906 HIV-1-infected patients came from about 100 municipalities of seven different macroregions of the Paraná State covered by representative units of the Ministry of Health, in the South region of Brazil. Of them, 1,127 (59.1\%) lived in cities with more than 100,000 inhabitants, 988 (51.8\%) were male, 1,459 (76.5\%) were Caucasians, 1,149 (60.3\%) aged 30-49 years old, and $855(44.9 \%)$ had 4 to 7 years of educational level. At baseline, 1,499 (78.6\%) patients showed undetectable HIV-1 VL

$\left(<1.70 \log _{10}\right.$ copies $\left./ \mathrm{mL}\right)$, and 325 (21.7\%) of them became non-sustained virologic responders during follow-up. Both immunologic and virologic responses to cART were found in 1,228 (64.4\%) patients at baseline and in 1,062 (55.7\%) during follow-up. Demographic variables were compared between the three groups of HIV-1 patients, as shown in Table 1. In the group of sustained virologic responders, we found higher frequency of patients that were male, older and with higher educational level than in the other two groups $(\mathrm{p}=0.002, \mathrm{p}<0.001, \mathrm{p}=0.026$ respectively). Initial CD $4+\mathrm{T}$ cells $>350 \mathrm{cells} / \mu \mathrm{L}$ was a more frequent phenomenon in the sustained virologic group (83.5\%) compared to those of nonsustained and non-virologic response ( $76 \%$ and $47.1 \%$, respectively); moreover, they showed higher frequency of CD4+ T cells $>500$ cells $/ \mu \mathrm{L}$ during follow-up than the other two groups $(\mathrm{p}<0.001)$.

The median time since diagnosis of HIV-1 infection was 7.4 years (IQR: 3.7-11.3) for the overall population and was not different between groups. HIV-1 patients who are sustained virologic responders were older than non-sustained or non-responders, with median of 46.0 years (IQR: 38.0-53.0), 43.0 years (IQR: 35.0-52.0), and 39.0 years (IQR: 32.0-46.0), respectively ( $\mathrm{p}<0.001$ ). Moreover, sustained virologic responders were under cART for a longer time than non-sustained or non-responders, with median of 5.8 years (IQR: 2.8-10.2), 4.9 years (IQR: 1.9-10.6) and 5.1 years (IQR: $1.9-11.2)$, respectively $(\mathrm{p}=0.024)$.

Multinomial logistic regression showed that non-responder patients had higher chances of being in the group of female and younger patients when compared to sustained virologic responders, as well as having baseline CD4+ $\mathrm{T}<200$ cells $/ \mu \mathrm{L}$ and worse CD4+ T recovery in the three-year follow up (Table 2).

\section{Immunologic response}

We were able to observe a progressive $\mathrm{CD} 4+\mathrm{T}$ increase in the group of sustained virologic response, when compared to the other groups. Sustained responders showed a CD4+ T mean of 639 cells $/ \mu \mathrm{L}$ in 2012 that increased to 672, 704 and 711 cells/ $\mu \mathrm{L}$ from 2013 to 2015, respectively. However, in nonsustained responders, CD4+ T mean showed a moderate increase from 559, 562, 570 to $571 \mathrm{cells} / \mu \mathrm{L}$, respectively, from 2012 to 2015 . The same pattern was observed in non-responders with values of 378, 394, 411 and 414cells/ $\mu$ L from 2012 until 2015 (Figure 1).

CD4+ T was analyzed in the three groups of HIV-1-infected patients to verify if they could achieve and/or maintain values $>350$ cell $/ \mu \mathrm{L}$ during the follow-up. We compared baseline CD4+ T cells with cART response in the next three-year follow-up and the results showed that patients with baseline $\mathrm{CD} 4+\mathrm{T}>350 \mathrm{cells} / \mu \mathrm{L}$ that continued with the same immunologic response in the following years 
Table 1

Demographic and clinical characteristics of patients infected with human immunodeficiency virus type 1 (HIV-1), according to their virologic response after combined antiretroviral therapy (CART), evaluated between 2012 and 2015.

\begin{tabular}{|c|c|c|c|c|c|c|c|c|c|}
\hline \multirow[t]{2}{*}{ Variables } & \multicolumn{2}{|c|}{$\begin{array}{l}\text { All patients } \\
(N=1,906)\end{array}$} & \multicolumn{2}{|c|}{$\begin{array}{l}\text { Sustained * } \\
(n=1,174)\end{array}$} & \multicolumn{2}{|c|}{$\begin{array}{c}\text { Non-sustained ** } \\
(n=325)\end{array}$} & \multicolumn{2}{|c|}{$\begin{array}{l}\text { Non-responder } * * * \\
\qquad(\mathrm{n}=407)\end{array}$} & \multirow[t]{2}{*}{ p-value } \\
\hline & $\mathbf{n}$ & $\%$ & $\mathbf{n}$ & $\%$ & $\mathbf{n}$ & $\%$ & $\mathbf{n}$ & $\%$ & \\
\hline \multicolumn{10}{|l|}{ Age (years) } \\
\hline $15-29$ & 169 & 8.9 & 67 & 5.7 a & 39 & $12.0 \mathrm{~b}$ & 63 & $15.5 b$ & $<0.001 \#$ \\
\hline $30-39$ & 519 & 27.2 & 283 & 24.1 a & 83 & 25.5 a & 153 & $37.6 \mathrm{~b}$ & \\
\hline $40-49$ & 630 & 33.1 & 405 & 34.5 a & 102 & 31.4 a & 123 & 30.2 a & \\
\hline$\geq 50$ & 588 & 30.8 & 419 & 35.7 a & 101 & 31.1 a & 68 & $16.7 \mathrm{~b}$ & \\
\hline \multicolumn{10}{|c|}{ Time of diagnosis (years) } \\
\hline$<5$ & 659 & 34.6 & 388 & 33.0 a & 124 & 38.2 a & 147 & 36.1 a & 0.116 \\
\hline $5-9$ & 593 & 31.1 & 381 & 32.5 a & 86 & $26.5 \mathrm{~b}$ & 126 & $31.0 \mathrm{a}, \mathrm{b}$ & \\
\hline $10-14$ & 473 & 24.8 & 292 & 24.9 a & 76 & 23.4 a & 105 & 25.8 a & \\
\hline$\geq 15$ & 181 & 9.5 & 113 & $9.6 a, b$ & 39 & 12.0 a & 29 & $7.1 \mathrm{~b}$ & \\
\hline \multicolumn{10}{|c|}{ Time under cART (years) } \\
\hline$<5$ & 887 & 46.5 & 523 & 44.5 a & 164 & 50.5 a & 200 & 49.1 a & 0.129 \\
\hline $5-9$ & 518 & 27.2 & 338 & 28.8 a & 73 & $22.5 \mathrm{~b}$ & 107 & $26.3 \mathrm{a}, \mathrm{b}$ & \\
\hline $10-14$ & 402 & 21.1 & 245 & 20.9 a & 71 & $21.8^{a}$ & 86 & 21.1 a & \\
\hline$\geq 15$ & 99 & 5.2 & 68 & 5.8 a & 17 & 5.2 a & 14 & 3.4 a & \\
\hline \multicolumn{10}{|l|}{ Sex } \\
\hline Female & 918 & 48.2 & 529 & 45.1 a & 177 & 54.5 b & 212 & $52.1 \mathrm{~b}$ & 0.002 \# \\
\hline Male & 988 & 51.8 & 645 & 54.9 a & 148 & $45.5 b$ & 195 & $47.9 \mathrm{~b}$ & \\
\hline \multicolumn{10}{|l|}{ Ethnicity } \\
\hline Caucasian & 1,459 & 76.5 & 911 & 77.6 a & 245 & 75.4 a & 303 & 74.4 a & 0.374 \\
\hline Non-Caucasian & 447 & 23.5 & 263 & 22.4 a & 80 & 24.6 a & 104 & 25.6 a & \\
\hline \multicolumn{10}{|c|}{ Educational level (years) } \\
\hline None & 36 & 1.9 & 27 & $2.3 a$ & 2 & 0.6 a & 7 & $1.8 \mathrm{a}$ & 0.026 \# \\
\hline $1-3$ & 237 & 12.4 & 137 & 11.9 a & 51 & 16.2 b & 49 & $12.3 \mathrm{a}, \mathrm{b}$ & \\
\hline $4-7$ & 855 & 44.9 & 525 & 45.5 a & 137 & 43.6 a & 193 & 48.5 a & \\
\hline $8-11$ & 524 & 27.5 & 314 & 27.2 a & 91 & 29.0 a & 119 & 29.9 a & \\
\hline$\geq 12$ & 213 & 11.2 & 150 & 13.0 a & 33 & $10.5 \mathrm{a}, \mathrm{b}$ & 30 & $7.5 \mathrm{~b}$ & \\
\hline Not known & 41 & 2.1 & & & & & & & \\
\hline \multicolumn{10}{|c|}{ Municipality of residence \#\# } \\
\hline Small & 540 & 28.3 & 331 & 28.2 a & 93 & 28.6 a & 116 & 28.5 a & 0.826 \\
\hline Medium & 239 & 12.5 & 143 & 12.2 a & 47 & 14.5 a & 49 & 12.0 a & \\
\hline Large & 1,127 & 59.1 & 700 & 59.6 a & 185 & 56.9 a & 242 & 59.5 a & \\
\hline \multicolumn{10}{|c|}{ CD4+ T count (cells $/ \mu \mathrm{L})$} \\
\hline \multicolumn{10}{|l|}{ Baseline (2012) } \\
\hline$<200$ & 174 & 9.1 & 37 & $3.2 \mathrm{a}$ & 21 & $6.5 b$ & 116 & $28.5^{c}$ & $<0.001 \#$ \\
\hline $200-350$ & 312 & 16.4 & 156 & 13.3 a & 57 & 17.5 a & 99 & $24.3 b$ & \\
\hline $351-500$ & 425 & 22.3 & 255 & 21.7 a & 86 & 26.5 a & 84 & 20.6 a & \\
\hline$>500$ & 995 & 52.2 & 726 & 61.8 a & 161 & $49.5 b$ & 108 & $26.5 c$ & \\
\hline \multicolumn{10}{|c|}{ Follow-up (2013-2015) } \\
\hline$<200$ & 130 & 6.8 & 18 & $1.5 \mathrm{a}$ & 13 & $4.0 \mathrm{~b}$ & 99 & $24.3 c$ & $<0.001 \#$ \\
\hline $200-350$ & 246 & 12.9 & 94 & 8.0 a & 49 & $15.1 \mathrm{~b}$ & 103 & $25.3 c$ & \\
\hline $351-500$ & 351 & 18.4 & 196 & 16.7 a & 75 & 23.1 b & 80 & 19.7 a,b & \\
\hline$>500$ & 1,179 & 61.9 & 866 & 73.8 a & 188 & $57.8 \mathrm{~b}$ & 125 & $30.7 c$ & \\
\hline \multicolumn{10}{|c|}{ CD4+ T slope (cells/ $\mu L / y e a r)$} \\
\hline$<-100$ & 160 & 8.4 & 93 & 7.9 a & 36 & $11.1 \mathrm{a}$ & 31 & 7.6 a & $0.001 *$ \\
\hline-99 to 0 & 632 & 33.2 & 358 & 30.5 a & 113 & $34.8 a, b$ & 161 & $39.6 b$ & \\
\hline+1 to +99 & 810 & 42.5 & 507 & 43.2 a & 134 & 41.2 a & 169 & 41.5 a & \\
\hline$>+100$ & 304 & 15.9 & 216 & 18.4 a & 42 & $12.9 \mathrm{~b}$ & 46 & $11.3 \mathrm{~b}$ & \\
\hline
\end{tabular}

* Sustained virologic responders: undetectable initial viral load (year 2012) and undetectable followed-up viral load (years 2013-2015);

** Non-sustained virologic responder: undetectable initial viral load (year 2012) and detectable followed-up viral load (years 2013-2015);

*** Non-virologic responder: detectable initial viral load (year 2012);

\# Significant at $\mathrm{p}<0.05$; differences are indicated by letters $(a, b, c)$;

\#\# Municipality size: small (<50,000 inhabitants); medium (50-100,000 inhabitants); large (> 100,000 inhabitants). 
Table 2

Multinomial logistic regression contrasting groups based on virologic response after combined antiretroviral therapy.

\begin{tabular}{|c|c|c|c|c|}
\hline \multirow{2}{*}{$\begin{array}{l}\text { Sustained responder * } \\
\text { (reference outcome group) }\end{array}$} & \multicolumn{2}{|c|}{ Non-sustained responder ** } & \multicolumn{2}{|c|}{ Non-responder $* * *$} \\
\hline & OR (95Cl) & p-value & OR $(95 \% \mathrm{Cl})$ & p-value \\
\hline \multicolumn{5}{|l|}{ Age (years) } \\
\hline $15-29$ & $2.57(1.58-4.19)$ & $<0.001$ & $8.52(5.05-14.35)$ & $<0.001$ \\
\hline $30-39$ & $1.25(0.88-1.78)$ & 0.216 & $4.04(2.74-5.95)$ & $<0.001$ \\
\hline $40-49$ & $1.04(0.75-1.43)$ & 0.831 & $2.03(1.39-2.98)$ & $<0.001$ \\
\hline$\geq 50$ & 1.00 & & 1.00 & \\
\hline \multicolumn{5}{|l|}{ Time of diagnosis (years) } \\
\hline$<5$ & $0.48(0.23-1.02)$ & 0.055 & $0.97(0.40-2.36)$ & 0.946 \\
\hline $5-9$ & $0.47(0.23-0.96)$ & 0.038 & $1.17(0.51-2.72)$ & 0.710 \\
\hline $10-14$ & $0.52(0.29-0.94)$ & 0.031 & $1.14(0.54-2.41)$ & 0.723 \\
\hline$\geq 15$ & 1.00 & & 1.00 & \\
\hline \multicolumn{5}{|l|}{ Time on CART (years) } \\
\hline$<5$ & $2.35(0.94-5.84)$ & 0.066 & $1.04(0.35-3.08)$ & 0.945 \\
\hline $5-9$ & $1.79(0.74-4.35)$ & 0.197 & $1.03(0.36-2.97)$ & 0.956 \\
\hline $10-14$ & $1.98(0.91-4.33)$ & 0.085 & $1.33(0.50-3.52)$ & 0.572 \\
\hline$\geq 15$ & 1.00 & & 1.00 & \\
\hline \multicolumn{5}{|l|}{ Sex } \\
\hline Male & 1.00 & & 1.00 & \\
\hline Female & $1.49(1.15-1.93)$ & 0.003 & $1.56(1.19-2.05)$ & 0.001 \\
\hline \multicolumn{5}{|l|}{ Educational level (years) } \\
\hline None & $0.37(0.08-1.68)$ & 0.199 & $1.50(0.50-4.52)$ & 0.470 \\
\hline $1-3$ & $1.65(0.98-2.77)$ & 0.059 & $1.66(0.92-3.02)$ & 0.094 \\
\hline $4-7$ & $1.13(0.73-1.76)$ & 0.569 & $1.62(0.99-2.64)$ & 0.055 \\
\hline 8-11 & $1.33(0.84-2.09)$ & 0.225 & $1.72(1.03-2.86)$ & 0.039 \\
\hline$\geq 12$ & 1.00 & & 1.00 & \\
\hline \multicolumn{5}{|l|}{ CD4+ T count (cells/ $\mu \mathrm{L})$} \\
\hline \multicolumn{5}{|l|}{ Baseline (2012) } \\
\hline$<200$ & $1.77(0.79-3.95)$ & 0.162 & $3.40(1.66-6.94)$ & 0.001 \\
\hline $200-350$ & $1.17(0.68-1.99)$ & 0.574 & $1.55(0.90-2.66)$ & 0.117 \\
\hline $351-500$ & $1.36(0.94-1.97)$ & 0.100 & $1.55(1.03-2.33)$ & 0.037 \\
\hline$>500$ & 1.00 & & 1.00 & \\
\hline \multicolumn{5}{|l|}{ Follow-up (2013-2015) } \\
\hline$<200$ & $1.93(0.70-5.29)$ & 0.201 & $18.82(8.29-42.74)$ & $<0.001$ \\
\hline $200-350$ & $2.11(1.20-3.73)$ & 0.010 & $5.98(3.44-10.40)$ & $<0.001$ \\
\hline $351-500$ & $1.58(1.07-2.35)$ & 0.022 & $2.37(1.56-3.62)$ & $<0.001$ \\
\hline$>500$ & 1.00 & & 1.00 & \\
\hline \multicolumn{5}{|l|}{ 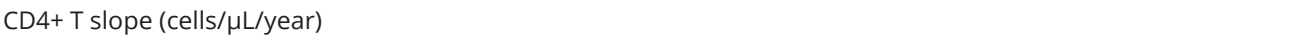 } \\
\hline$<-100$ & $2.13(1.21-3.74)$ & 0.009 & $1.76(0.94-3.30)$ & 0.077 \\
\hline-99 to 0 & $1.55(0.99-2.42)$ & 0.052 & $1.29(0.80-2.08)$ & 0.293 \\
\hline+1 to +99 & $1.20(0.80-1.81)$ & 0.381 & $1.05(0.68-1.61)$ & 0.833 \\
\hline$>+100$ & 1.00 & & 1.00 & \\
\hline
\end{tabular}

95\%Cl: confidence interval; OR: odds ratio.

* Sustained virologic responders: undetectable initial viral load (year 2012) and undetectable followed-up viral load (years 2013-2015);

** Non-sustained virologic responder: undetectable initial viral load (year 2012) and detectable followed-up viral load (years 2013-2015);

*** Non-virologic responder: detectable initial viral load (year 2012). 
Figure 1

CD4+ T cell count (cells/ $\mu \mathrm{L}$ ) obtained during the follow-up period (2012 to 2015), according to virologic response to combined antiretroviral therapy. The values are expressed as mean and $95 \%$ confidence interval $(95 \% \mathrm{Cl})$.
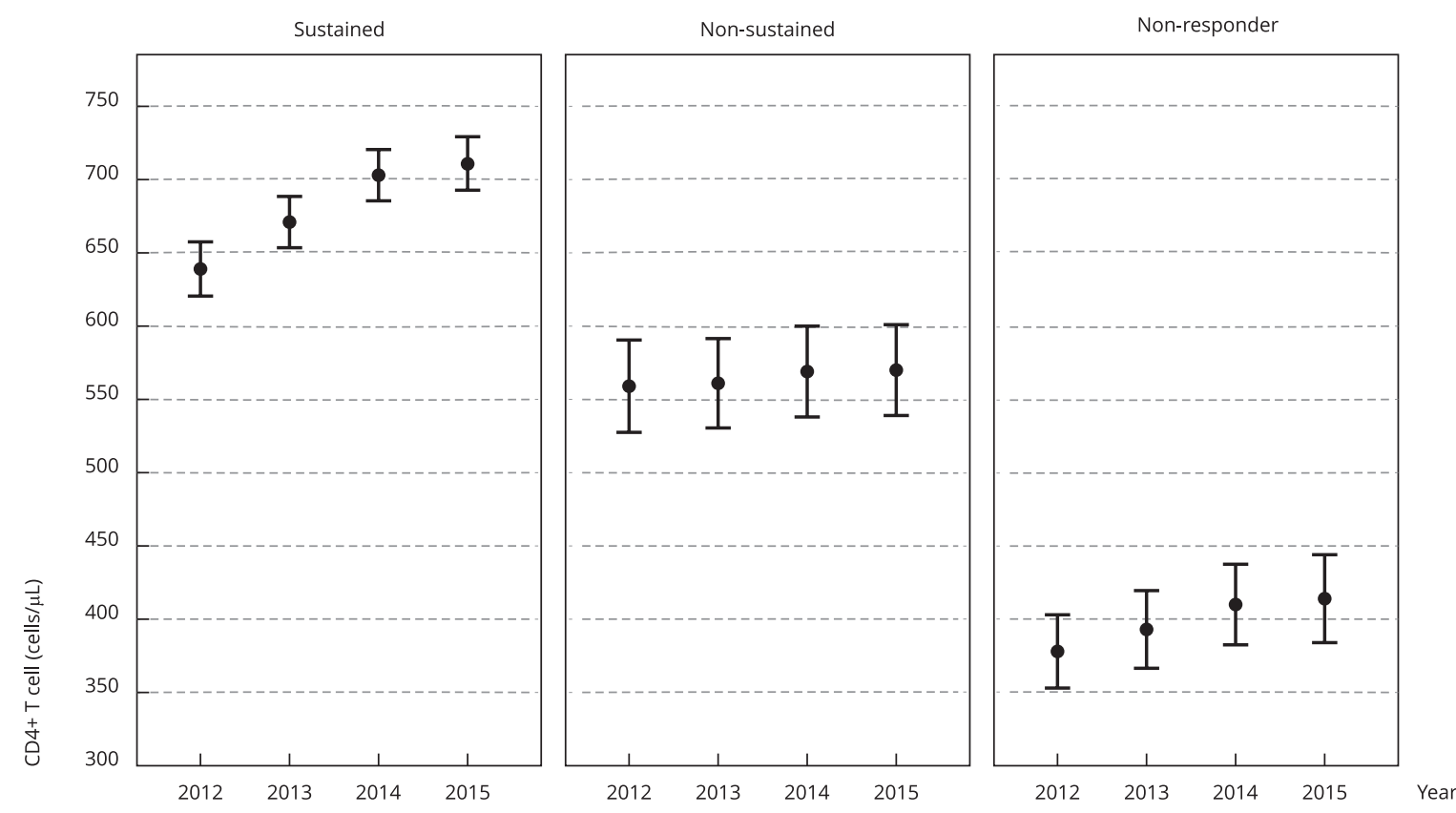

were $94.1 \%, 81.8 \%$ and $71.9 \%$ among the sustained, non-sustained and non-virologic responders to therapy, respectively. Concomitant sustained virologic and immunologic responses had more chance to be observed in female $(\mathrm{OR}=50.5$; 95\%CI: $25.8-98.9)$ than male patients $(\mathrm{OR}=33.8$; 95\%CI: 20.1 56.8) (Table 3).

\section{Discussion}

In this study, we evaluated the peripheral blood CD4+ T cells and HIV-1 VL in chronic HIV-1-infected patients under cART during three-year follow-up. We conducted a convenience sampling based on our laboratory routine for cART monitoring, in agreement with the regulations of the Brazilian Ministry of Health for rational use of CD4+ T cell testing by public laboratories by the time this study was performed. One important finding of this study was that $94.1 \%$ of patients that were sustained virologic responders with initial CD4+ $\mathrm{T}>350$ cells $/ \mu \mathrm{L}$ maintained the appropriate immunologic response during the three-year follow-up. This result underscored that the medical request of CD4+ $\mathrm{T}$ cell may be requested at long-term intervals or even abolished from medical practice without any impairment for evaluating cART response in these patients. Another finding was the high rates of patients that were responders under cART. At baseline, $64.4 \%$ of patients were both virologic and immunologic responders, demonstrating that the use of cART has achieved its goals of VL suppression and immune response restoration in a large amount of patients.

In the period of 2000 to 2011, the unitary cost of CD4+ T cell counts and HIV-1 VL measurement paid by Brazilian governmental sources was of about USD 17.62 and USD 20.34, respectively 6. We 
Table 3

Immunologic outcome, expressed as CD4+ T cell count, in male and female patients infected with human immunodeficiency virus type 1 (HIV-1), according to their virologic response considering a threshold of $350 \mathrm{cells} / \mu \mathrm{L}$.

\begin{tabular}{|c|c|c|c|c|c|c|c|c|}
\hline \multirow{3}{*}{$\begin{array}{l}\text { Virologic response/Initial CD4 count } \\
(\text { cells/ } \mu \mathrm{L})\end{array}$} & \multicolumn{4}{|c|}{ Outcome CD4+ $\mathrm{T}$ cell count } & \multicolumn{2}{|c|}{ Total } & \multirow[t]{3}{*}{ OR $(95 \% \mathrm{CI})$} & \multirow[t]{3}{*}{ p-value } \\
\hline & \multicolumn{2}{|c|}{$\leq 350 \mathrm{cells} / \mu \mathrm{L}$} & \multicolumn{2}{|c|}{$>350$ cells $/ \mu \mathrm{L}$} & \multirow[b]{2}{*}{$\mathbf{n}$} & \multirow[b]{2}{*}{$\%$} & & \\
\hline & $\mathbf{n}$ & $\%$ & $\mathbf{n}$ & $\%$ & & & & \\
\hline \multicolumn{9}{|l|}{ Male patients } \\
\hline \multicolumn{9}{|l|}{ Sustained * } \\
\hline$\leq 350$ & 87 & 72.5 & 33 & 27.5 & 120 & 100.0 & & \\
\hline$>350$ & 38 & 7.2 & 487 & 92.8 & 525 & 100.0 & $33.8(20.1-56.8)$ & $<0.001$ \\
\hline \multicolumn{9}{|l|}{ Non-sustained ** } \\
\hline$\leq 350$ & 30 & 81.1 & 7 & 18.9 & 37 & 100.0 & & \\
\hline$>350$ & 18 & 16.2 & 93 & 83.8 & 111 & 100.0 & $22.1(8.4-58.1)$ & $<0.001$ \\
\hline \multicolumn{9}{|l|}{ Non-responder $* * *$} \\
\hline$\leq 350$ & 102 & 91.1 & 10 & 8.9 & 112 & 100.0 & & \\
\hline$>350$ & 25 & 30.1 & 58 & 69.9 & 83 & 100.0 & $23.7(10.6-52.7)$ & $<0.001$ \\
\hline Total & 300 & 30.4 & 688 & 69.6 & 988 & 100.0 & & \\
\hline \multicolumn{9}{|l|}{ Female patients } \\
\hline \multicolumn{9}{|l|}{ Sustained * } \\
\hline$\leq 350$ & 51 & 69.9 & 22 & 30.1 & 73 & 100.0 & & \\
\hline$>350$ & 20 & 4.4 & 436 & 95.6 & 456 & 100.0 & 50.5 (25.8-98.9) & $<0.001$ \\
\hline \multicolumn{9}{|l|}{ Non-sustained ** } \\
\hline$\leq 350$ & 33 & 80.5 & 8 & 19.5 & 41 & 100.0 & & \\
\hline$>350$ & 27 & 19.9 & 109 & 80.1 & 136 & 100.0 & $16.6(6.9-40.1)$ & $<0.001$ \\
\hline \multicolumn{9}{|l|}{ 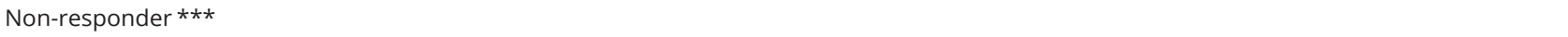 } \\
\hline$\leq 350$ & 89 & 86.4 & 14 & 13.6 & 103 & 100.0 & & \\
\hline$>350$ & 29 & 26.6 & 80 & 73.4 & 109 & 100.0 & $17.5(8.6-35.5)$ & $<0.001$ \\
\hline Total & 249 & 27.1 & 669 & 72.9 & 918 & 100.0 & & \\
\hline \multicolumn{9}{|l|}{ All patients } \\
\hline \multicolumn{9}{|l|}{ Sustained * } \\
\hline$\leq 350$ & 138 & 71.5 & 55 & 28.5 & 193 & 100.0 & & \\
\hline$>350$ & 58 & 5.9 & 923 & 94.1 & 981 & 100.0 & $39.9(26.5-60.2)$ & $<0.001$ \\
\hline \multicolumn{9}{|l|}{ Non-sustained ** } \\
\hline$\leq 350$ & 63 & 80.8 & 15 & 19.2 & 78 & 100.0 & & \\
\hline$>350$ & 45 & 18.2 & 202 & 81.8 & 247 & 100.0 & $18.8(9.8-36.1)$ & $<0.001$ \\
\hline \multicolumn{9}{|l|}{ Non-responder $* * *$} \\
\hline$\leq 350$ & 191 & 88.8 & 24 & 11.2 & 215 & 100.0 & & \\
\hline$>350$ & 54 & 28.1 & 138 & 71.9 & 192 & 100.0 & $20.3(12.0-34.5)$ & $<0.001$ \\
\hline Total & 549 & 28.8 & 1,357 & 71.2 & 1906 & 100.0 & & \\
\hline
\end{tabular}

95\% Cl: confidence interval; OR: odds ratio.

* Sustained virologic responders: undetectable initial viral load (year 2012) and undetectable followed-up viral load (years 2013-2015);

** Non-sustained virologic responder: undetectable initial viral load (year 2012) and detectable followed-up viral load (years 2013-2015);

*** Non-virologic responder: detectable initial viral load (year 2012).

believe that the resistance of physicians in maintaining medical requests of CD4+ $\mathrm{T}$ cell exams reflect the fear that appropriate initial values of this cell could fall without any possibility of following this decrease. A similar study observed a decrease of only $9 \%$ below the threshold of 350 cells $/ \mu \mathrm{L}$, and in $61.5 \%$ of cases it was a transient situation 7 . Using different criteria for virologic and immunologic responses, other studies also reported high maintenance rates above the defined threshold, and the low CD4+ T cell count resumed increase without intervention in most of the cases $8,9,10$. This result confirms that there is no impairment in the treatment of HIV-1-infected patients when CD4+ T cells 
were not verified as frequently as before, and that maintaining the old recommendation generates unnecessary costs. Furthermore, these patients evaluate their HIV-1 VL every six months to verify any risk of virologic failure, and when an increase in VL is observed, it is recommended that a new CD4+ T cells evaluation be performed.

One other finding of that study was that the frequency of sustained virologic response was lower amongst female patients; however, once immunologic response was activated, female patients showed a higher chance of maintaining both immunologic and sustained virologic responses when compared to male patients. One study also showed better virologic outcome in male HIV-1 patients than their female partners 11. Other two studies found better immune reconstitution among women 12,13. In another study, CD4+ T cell increase was higher in female patients during the 5-year follow up, but there was a certain delay to achieve virologic suppression among women, in that frequencies of $\mathrm{VL}<$ 50 copies $/ \mathrm{mL}$ were significantly lower among women in the first and second years of follow up, but these frequencies were similar for both sexes at the end of the evaluation period 14. Regarding the ethnicity of HIV-1 patients enrolled in our study, no difference was observed between Caucasians and non-Caucasians regarding therapy response. Different results have been reported, such as a previous study showing that Hispanic and Caucasian women had significantly lower hazards of virologic failure than African American women, and those who experienced virologic failure were more likely to be African American, younger, have lower CD4+ T cells, and history of virologic failure 15 . Women were also associated with increased mortality and significant disparities in cART adoption among HIV-1-infected individuals receiving health care. Women presented younger age and higher CD4+ T cells as well as lower baseline HIV-1 RNA VL than men. Black people presented lower CD4+ T cells and higher HIV-1 RNA VL than non-Black people 16. The prognosis of HIV-1 infection is poorer for Black people than Caucasians in the United States. Minority racial/ethnic groups (mostly Black people) are more likely to discontinue cART earlier and experience virologic failure. These differences may be explained by notably common characteristics in Black HIV-1-infected individuals, such as young age, lower education level, pretreatment characteristics (higher HIV-1 RNA VL and lower CD4+ T), non-adherence to medication, and lower access to health care than non-Black HIV-1 infected individuals 17 .

Peripheral CD4+ T cell increase under treatment is a three-stage process, whichever the regimen of drugs may be, as follows: (1) during the first 1-6 months of cART, the average rate of reconstitution is of 20-30cells/ $\mu \mathrm{L}$ monthly; (2) a second stage that remains until the end of the second year of therapy represents an increase of about $5-10$ cells/ $\mu \mathrm{L}$ monthly; (3) the third stage that extends beyond the second year for at least 7 years shows an increase of about $2-5$ cells/ $\mu \mathrm{L}$ monthly 18 . This explains the progressive increase in CD4+ T cells observed from one year to the other in all three groups of patients of this study. This result is consistent with a study carried out in an Ugandan cohort where CD4+ T cell levels increased continuously throughout the 10-year follow-up, and $83.8 \%$ of the patients reached CD4+ T cell amounts above the lower reference value ${ }^{19}$. In an Asian study with 6,521 HIV-1-infected patients, there was a positive increase over time in CD4+ T cells gains and in the proportion of patients with VL suppression 20.

In this study, the sustained virologic responders to cART were most likely to occur among older than younger patients. Other studies have demonstrated an association between age and virologic suppression 21,22. It is not well explained why older subjects develop better virologic responses to cART than younger subjects, but some factors are better adherence to the treatment, more favorable pharmacokinetics or better access to health care for older people than young people. Maturity and personal stability in older people may contribute to adherence, this way decreasing the risk of virologic failure when compared to younger individuals $23,24,25$.

According to previous report, sub-optimal CD4+ T cell recovery after initiation of suppressive cART is a phenomenon observed with a prevalence of $7 \%-41 \% 24$. Most patients in virologic response to cART exhibit sustained increases in peripheral CD4+ T cells, but a significant subset of individuals, $15-40 \%$, clearly do not achieve this desired outcome and fail to achieve a satisfactory CD4+ T cell reconstitution 26. It appears to be particularly true among those individuals who delayed the cART until their CD4+ T cells decrease to levels below 200cells/ $\mu \mathrm{L}$, because they trend toward maintaining values that plateaus in the 200-350cells/ $\mu \mathrm{L}$ range, even after up to ten years of effective therapy 25 . A Spanish study sampling cART naïve patients with initial CD4+ T<200cells/ $\mu \mathrm{L}$ and found that 
69.9\% and 64.4\% reached immunologic and virologic response, respectively, at the end of the fiveyear follow-up 27 . About $32.7 \%$ of patients with CD4+ T $<100$ cell/ $\mu \mathrm{L}$ and VL suppressed for up to 5 -year follow-up failed to achieve CD4+ T $>350$ cells/ $\mu \mathrm{L}$, and the proportion of people reaching this threshold after one and three years of VL suppression was $14 \%$ and $59 \%$, respectively 28 . Older age and more than one year of severe immune deficiency prior to start of sustained VL were associated with insufficient immunologic response and increased long term mortality 29 . Patients who start cART at a baseline CD4+ T $>350$ cells/ $\mu \mathrm{L}$ have greater chance to achieve $>500$ cells $/ \mu \mathrm{L}$, which afford greater protection against clinical progression and better survival rates 20,30 .

Discordant immunologic and virologic responses are surrounded by many uncertainties, some of them related to the absence of a uniform definition of ideal immune response and to the limitations imposed by CD4+ T cells as the only marker of immune reconstitution available in daily practice 31 . If the definition of immune response is based exclusively on the CD4+ T cells reached rather than CD4+ T cells slope, the baseline CD4+ T cells certainly influence the level of immune response. CD4+ $\mathrm{T}$ cells response has been reported to be low when pre-therapeutic viremia is low, but the reasons for this correlation remain unclear 18 .

For patients presenting late to care, CD4+ T cells continue to play an important role in decisions about cART initiation and clinical management, and may remain an important laboratorial biomarker to monitor cART in settings where VL monitoring is still restricted 32.

This study has some limitations that deserve to be discussed. We do not have any robust data about the regular use of cART by the patients as well as the presence or absence of symptoms at the time of examination. Therefore, it is neither possible to claim which patients have good adherence to cART nor whether the decrease in CD4+ T cells or the increase in VL were associated with clinical symptoms. Therefore, in this study it is not possible to attribute the absence of virologic and/or immunologic response to HIV-1 strain resistance or inadequate use of cART. Another limitation is the lack of data on the type of cART that was associated with increases in CD4+ T cells. Moreover, the presence of coinfections was not considered in this study, such as the hepatitis C virus (HCV), which has been associated with incomplete CD4+ T cells regeneration 33,34.

Advantages of our study include its extension and broad range of patients originally from different settings of care and with wide variation in relevant clinical characteristics, such as mode of transmission, age and extent of immune suppression before starting cART. Therefore, our results may be applicable to patients with HIV-1 infection followed in other clinical centers in countries, which are sustained responders after starting cART.

\section{Conclusion}

Considered together, the results underscore that HIV-1-infected patients that are sustained virologic responders and have initial CD4+ $\mathrm{T}>350$ cells/ $\mu \mathrm{L}$ presented more chance to maintain CD4+ $\mathrm{T}$ cell counts above this threshold during the next three-year follow-up. This result supports that the evaluation of CD4+ T cell count at long-term intervals may not impair the evaluation of cART response in these patients. 


\section{Contributors}

I. H. Vogler made substantial contributions to conception and design, data collection, analysis and interpretation of data; drafting the article and reviewing it critically for important intellectual content; and final approval of the version to be published. D. F. Alfieri participated in data collection, analysis and interpretation of data, and final approval of the version to be published. H. D. B. Gianjacomo participated in the laboratory tests and approval of the final version of the manuscript. E. R. D. Almeida participated in the critical review and approval of the final version of the manuscript. E. M. V. Reiche made substantial contributions to conception and design, data collection, analysis and interpretation of data; drafting the article and reviewing it critically for important intellectual content; and final approval of the version to be published.

\section{Acknowledgments}

The authors acknowledge Prof. Dr. Mariana Ragassi Urbano for statistical assistance. This study did not count on financial support from funding agencies.

\section{Confict of interest}

The authors declare no conflicts of interest.

\section{References}

1. World Health Organization. Consolidated guidelines on the use of antiretroviral drugs for treating and preventing HIV infection: recommendations for a public health approach. 2nd Ed. Geneva: World Health Organization; 2016.

2. Secretaria de Vigilância em Saúde, Ministério da Saúde. Protocolo clínico e diretrizes terapêuticas para manejo da infecção pelo HIV em adultos. http://www.aids. gov.br/sites/default/files/anexos/publica cao/2014/55939/08_05_2014_protocolo_pe diatrico_pdf_36225.pdf (accessed on 30/Mar/ 2013).

3. Ministério da Saúde. Recomendações para terapia antirretroviral em adultos e adolescentes infectados pelo HIV: 2005/2006. 6a Ed. Brasília: Ministério da Saúde; 2006.

4. Secretaria de Vigilância em Saúde, Ministério da Saúde. Protocolo clínico e diretrizes terapêuticas para manejo da infecção pelo HIV em adultos. http://www.aids.gov.br/sites/default/ files/anexos/publicacao/2013/55308/proto colofinal_31_7_2015_pdf_31327.pdf (accessed on 20/Jul/2017).

5. Falster K, Petoumenos K, Chuah J, Mijch A, Mulhall B, Kelly M, et al. Poor baseline immune function predicts an incomplete immune response to combination antiretroviral treatment despite sustained viral suppression. J Acquir Immune Defic Syndr 2009; 50:307-13.

6. Belaunzarán-Zamudio PF, Caro-Vega YN, Shepherd BE, Crabtree-Ramírez BE, Luz PM, Grinsztejn B, et al. Monitoring of HIV treatment in seven countries in the WHO region of the Americas. Bull World Health Organ 2015; 93:529-39.

7. Whitlock GG, Ahmed N, Benn P, Edwards S, Waters L. Stop routine CD4 monitoring in HIV-infected patients with fully suppressed virus and CD $4 \geq 350$ cells $/ \mathrm{mL}$. Clin Infect Dis 2013; 57:327-8.

8. Ford N, Stinson K, Davies MA, Cox V, Patten $\mathrm{G}$, Cragg $\mathrm{C}$, et al. Is it safe to drop CD4+ monitoring among virologically suppressed patients: a cohort evaluation from Khayelitsha, South Africa. AIDS 2014; 28:2003-5.

9. Reynolds SJ, Sempa JB, Kiragga AN, Newell K, Nakigozi G, Galiwango R, et al. Is CD4 monitoring needed among ugandan clients achieving a virologic and immunologic response to treatment? AIDS Patient Care STDS 2014; 28:575-8.

10. Gale HB, Gitterman SR, Hoffman HJ, Gordin FM, Benator DA, Labriola AM, et al. Is frequent CD4+ T-lymphocyte count monitoring necessary for persons with counts $>300$ cells/ $\mathrm{uL}$ and HIV-1 suppression? Clin Infect Dis 2013; 56:1340-3.

11. Syed IA, Sulaiman SA, Hassali MA, Syed SH, Shan LH, Lee CK. Factors associated with poor CD4 and viral load outcomes in patients with HIV/AIDS. J Med Virol 2016; 88:790-7. 
12. Maman D, Pujades-Rodriguez M, Subtil F, Pinoges L, McGuire M, Ecochard R, et al. Gender differences in immune reconstitution: a multicentric cohort analysis in Sub-Saharan Africa. PLoS One 2012; 7:e31078.

13. Bastard M, Soulinphumy K, Phimmasone P, Saadani AH, Ciaffi L, Communier A, et al. Women experience a better long-term immune recovery and a better survival on HAART in Lao People's Democratic Republic. BMC Infect Dis 2013; 13:27.

14. 'Rosin C, Elzi L, Thurnheer C, Fehr J, Cavassini M, Calmy A, et al. Gender inequalities in the response to combination antiretroviral therapy over time: the Swiss HIV cohort study. HIV Med 2015; 16:319-25.

15. McFall AM, Dowdy DW, Zelaya CE, Murphy $\mathrm{K}$, Wilson TE, Young MA, et al. Understanding the disparity: predictors of virologic failure in women using highly active antiretroviral therapy vary by race and/or ethnicity. J Acquir Immune Defic Syndr 2013; 64:289-98.

16. Lemly DC, Shepherd BE, Hulgan T, Rebeiro P, Stinnette S, Blackwell RB, et al. Race and sex differences in antiretroviral therapy use and mortality among HIV-infected persons in care. J Infect Dis 2009; 199:991-8.

17. Ribaudo HJ, Smith KY, Robbins GK, Flexner C, Haubrich R, Chen Y, et al. Racial differences in response to antiretroviral therapy for HIV infection: an AIDS Clinical Trials Group (ACTG) study analysis. Clin Infect Dis 2013; 57:1607-17.

18. Corbeau P, Reynes J. Immune reconstitution under antiretroviral therapy: the new challenge in HIV-1 infection. Blood 2011; 117:5582-90.

19. Castelnuovo B, Kiragga A, Musaazi J, Sempa J, Mubiru F, Wanyama J, et al. Outcomes in a cohort of patients started on antiretroviral treatment and followed up for a decade in an urban clinic in Uganda. PLoS One 2015; 10:e0142722.

20. Jiamsakul A, Mean CV, Saphonn V, Zhang FJ, Lee MP, Kumarasamy N. A decade of combination antiretroviral treatment in Asia: the TREAT Asia HIV observational database cohort. AIDS Res Hum Retroviruses 2016; 32:772-81

21. Weintrob AC, Fieberg AM, Agan BK, Ganesan A, Crum-Cianflone NF, Marconi VC, et al. Increasing age at HIV seroconversion from 18 to 40 years is associated with favorable virologic and immunologic responses to HAART. J Acquir Immune Defic Syndr 2008; 49:40-7.

22. Althoff KN, Justice AC, Gange SJ, Deeks SG, Saag MS, Silverberg MJ, et al. Virologic and immunologic response to HAART, by age and regimen class. AIDS 2010; 24:2469-79.

23. Van Lelyveld SF, Gras L, Kesselring A, Zhang S, De Wolf F, Wensing AM, et al. Long-term complications in patients with poor immunological recovery despite virological successful HAART in Dutch ATHENA cohort. AIDS 2012; 26:465-74
24. Onen NF, Overton ET, Presti R, Blair C, Powderly WG, Mondy K. Sub-optimal CD4 recovery on long-term suppressive highly active antiretroviral therapy is associated with favorable outcome. HIV Med 2009; 10:439-46.

25. Kelley CF, Kitchen CM, Hunt PW, Rodriguez $\mathrm{B}$, Hecht FM, Kitahata $\mathrm{M}$, et al. Incomplete peripheral CD4+ cell count restoration in HIV-infected patients receiving long-term antiretroviral treatment. Clin Infect Dis 2009; 48:787-94.

26. Gaardbo JC, Hartling HJ, Gerstoft J, Nielsen $\mathrm{SD}$. Incomplete immune recovery in HIV infection: mechanisms, relevance for clinical care, and possible solutions. Clin Dev Immunol 2012; 2012:670957.

27. Ferrer E, Curto J, Esteve A, Miro JM, Tural C, Murillas J, et al. Clinical progression of severely immunosuppressed HIV-infected patients depends on virological and immunological improvement irrespective of baseline status. J Antimicrob Chemother 2015; 70:3332-8.

28. O'Connor JL, Smith CJ, Lampe FC, Hill T, Gompels M, Hay P, et al. Failure to achieve a CD4+ cell count response on combination antiretroviral therapy despite consistent viral load suppression. AIDS 2014; 28:919-24.

29. Engsig FN, Gerstoft J, Kronborg G, Larsen CS, Pedersen G, Røge B, et al. Long-term mortality in HIV patients virally suppressed for more than three years with incomplete CD4 recovery: a cohort study. BMC Infect Dis 2010; 10:318.

30. Moore RD, Keruly JC. CD4+ cell count 6 years after commencement of highly active antiretroviral therapy in persons with sustained virologic suppression. Clin Infect Dis 2007; 44:441-6.

31. Casotti JA, Passos LN, Oliveira FJ, Cerutti Jr. C. Prevalence of discordant immunologic and virologic responses in patients with AIDS under antiretroviral therapy in a specialized care center in Brazil. Rev Inst Med Trop São Paulo 2011 53:301-7.

32. Ford N, Meintjes G, Pozniak A, Bygrave H, Hill A, Peter T, et al. The future role of CD4 cell count for monitoring antiretroviral therapy. Lancet Infect Dis 2015; 15:241-7.

33. Seminari E, Tinelli C, Ravasi G, Ripamonti D, Ladisa N, Marino N, et al. Hepatitis C infection on immune recovery in HIV-positive patients on successful HAART: the role of genotype 3. Curr HIV Res 2010; 8:186-93.

34. Santin M, Mestre M, Shaw E, Barbera MJ, Casanova A, Niubo J, et al. Impact of hepatitis C virus coinfection on immune restoration during successful antiretroviral therapy in chronic human immunodeficiency virus type 1 disease. Eur J Clin Microbiol Infect Dis 2008; 27:65-73. 


\section{Resumo}

$O$ último consenso brasileiro recomenda reduzir a rotina de contagem de linfócitos $T$ CD4+ para monitorar os pacientes com HIV-1 sob terapia antirretroviral combinada (TARV). O estudo teve como objetivo avaliar a segurança do monitoramento à TARV na infecção pelo HIV-1, realizando a carga viral a intervalos mais curtos e a contagem de linfócitos TCD4+ a intervalos mais longos. Foram avaliadas a contagem de linfócitos $T C D 4+e$ a carga viral do HIV-1 em 1.906 pacientes com HIV1 em uso de TARV durante um seguimento de três anos. Os pacientes foram estratificados em: resposta sustentada, não sustentada e não respondedores. As proporções de pacientes com linfócitos $T$ CD4+ > 350células/ $\mu$ L na linha de base do estudo entre de resposta sustentada, não sustentada e não respondedores à TARV e que permaneceram com valores acima desse limiar ao longo do seguimento foram 94,1\%, 81,8\% e 71,9\%, respectivamente. Os pacientes com resposta virológica sustentada e que tinham contagem de T CD4+ > 350células/ $\mu L$ mostraram maior probabilidade de manter a contagem acima desse limiar durante o seguimento, quando comparados àqueles com T CD4+ $\leq 350$ células/ $\mu L(O R=39,9 ; 95 \%$ CI: 26,5-60,2; $p$ $<0,001)$. O estudo mostrou que pacientes HIV-1+ com resposta virológica sustentada e contagem de linfócitos T CD4+ > 350células/ $\mu$ L tinham maior probabilidade de manter a contagem de células $T$ CD4+ acima desse limiar durante o seguimento de três anos subsequentes. O resultado corrobora que a contagem de linfócitos $T$ CD4+ com intervalos mais longos não compromete a segurança do monitoramento da resposta à TARV quando a avaliação da carga viral é feita de rotina em pacientes HIV-1+ com resposta virológica sustentada.

Contagem de Linfócito CD4; HIV-1; Terapia Antirretroviral de Alta Atividade; Carga Viral

\section{Resumen}

Las últimas directrices brasileñas recomendaron la reducción de la rutina en el recuento celular CD4+ T para pacientes con el virus de inmunodeficiencia humano tipo 1 (VIH-1), con terapia de combinación antirretroviral (cART por sus siglas en inglês). El objetivo de este estudio fue evaluar la seguridad de la monitorización de la respuesta a la cART en una infección por VIH-1, usando rutinas de carga viral en intervalos más cortos $y$ recuento celular $C D 4+T$ en intervalos más largos. Se evaluaron el recuento celular CD4+ T y la carga viral VIH-1 en 1.906 pacientes infectados con VIH- 1 y con cART durante un seguimiento que duró tres años. Los pacientes fueron estratificados como constantes, inconstantes y sin respuesta. La proporción de pacientes que mostraron $C D 4+T>$ 350 células/ $\mu L$ en el estudio entran dentro del grupo de los constantes, inconstantes y sin respuesta al cART, y quienes permanecieron con valores por encima de este umbral durante los seguimientos fueron $94,1 \%, 81,8 \%$ y 71,9\%, respectivamente. Los pacientes infectados por VIH-1 que cuentan con la respuesta virológica constante y tienen un recuento inicial CD $4+T>350$ células/ $\mu L$ mostraron una oportunidad más alta de mantener el recuento de estas células por encima del umbral durante los seguimientos, respecto a quienes presentaban CD4+ T células $\leq 350$ células/ $\mu L(O R=39$, 9; IC95\%: 26,5-60,2; $p<0,001)$. Este estudio expuso que los pacientes infectados por VIH-1, que habian tenido una respuesta virológica constante e inicial CD4+ $T>350$ células $/ \mu L$, eran más propensos a mantener el recuento de células $C D 4+T$ por encima de este umbral durante los tres años posteriores de seguimiento. Este resultado destaca que la evaluación del cómputo de células CD4+ T en intervalos más largos no obstaculiza la seguridad al realizar una monitorización en la respuesta a cART, cuando la evaluación de la carga viral rutinaria se realiza en pacientes infectados por VIH-1 con una respuesta virológica constante.

Recuento de Linfocito CD4; VIH-1; Terapia Antirretroviral Altamente Activa; Carga Viral

Submitted on $19 / \mathrm{Jan} / 2018$

Final version resubmitted on 29/May/2018

Approved on 08/Jun/2018 